\title{
Legal Status of the Embryo in Legislation of the Republic of Yemen: Comparative Research on Provisions of the Islamic and International Law
}

\author{
Tarhanov Ildar Abdulhakovich
}

Fadhl Enghadh Ahmed

Kazan (Volga region) Federal University, 18 Kremlevskaya str., 420008, Kazan, Russia

\section{Doi:10.5901/mjss.2014.v5n24p492}

\begin{abstract}
The article touches upon the problem of determining status and protection of the rights of the embryo in the legislation of the Republic of Yemen from the point of view of the Islamic and international law.
\end{abstract}

Keywords: legal status of the embryo, Legislation and the Republic of Yemen, Islamic law, international law in the status of the embryo.

Embryo is a stage of development of an organism from zygote to birth or breaking the eggshell. Prenatal development of a human being lasts for about 270 days and is usually divided into embryo (germ) and fetal periods.

The Quran contains data embracing periods from preliminary development of a human embryo to birth: "Indeed, We created man out of an extract of clay. Thereafter We put it as a drop into a safe lodging. Then We made the drop into a clot, then We made the clot into a little lump of flesh, then We made out of that little lump of flesh bones, then We clothed the bones with flesh, and then We brought it forth as another creation. So blessed be Allah, the Best of creators [2]".

The problem of protection of the right of the embryo has not been carefully studied yet, though attempts to work out new doctrines on protection of these rights have been made both in the Islamic and international law. At the same time, it should be pointed out that fundamentals of the Islamic doctrine should be close in such a way to make an integral part of regulation in the international law. Meanwhile, we can hardly misunderstand that the Islamic system of legal norms and religious and moral rules established by the Quran and Sunnah cannot fit in full degree or be similar to all elements of regulation in the international law. It should be pointed out that, in our view, the problem of interpretation of rights of the embryo is not sufficiently studied in some other social and political sciences that are not associated with the Arab world.

Theory of human rights is under careful consideration in the international law. However, main fundamentals of the Islamic law have not yet received adequate attention in the context of international legal prescriptions. We have to admit that in many cases international lawyers are prejudiced against some provisions of the Islamic law. This deprives a research from objectivity and in many cases can distort its main point. Obviously, this results in misinterpretation of some approaches and provisions of the Islamic law concerning human rights and protection of rights of children.

Comparing fundamentals of the relevant conceptions in the international and Islamic law, it is important to give a fair view to protection of rights of the embryo in the Islamic law, in the classical (the Quran and the Sunnah) and the modern Yemen law at the constitutional and field specific levels. We assume that this conception has an international legal component. Especially since rights of the embryo, as a legal phenomenon, have not always been subject of independent research.

The Islamic law presumes that children are the divine mercy and a natural human need. The Islamic Sharia encourages people to give birth to children in order to preserve the human race and prohibits sterilization of men and women, hysterectomy, abortion unless medically necessary, any methods that can terminate reproduction of humankind. A child enjoys the right to be born from a lawful marriage between a man and a woman [3]. The role of children in Islam, the essence and wisdom of reproduction are reflected in one of ayats of the Quran:

"Wealth and children are the adornment of the life of this world. But the good righteous deeds that last, are better with your Lord for rewards and better in respect of hope" [4]. "To Allah belongs the kingdom of the heavens and the earth. He creates what He wills. He bestows female offspring upon whom He wills, and bestows male offspring upon whom He wills. Or He bestows both males and females, and He renders barren whom He wills. Verily, He is the AllKnower and is Able to do all things" [5]. This ayat reveals that children are a gift and mercy of the Almighty, that love to children, male or female, is in nature of every human being and is one of virtues of this world reminding us of a greater 
mercy that we can get in the other world only if we live the just life.

We can conclude that rights of a future child are protected in the Islamic Sharia before its parents are married. Exercise of this right determines the atmosphere in which a child would grow. Parents are considered the best protectors of rights of their child. Therefore Islam pays much attention to instructing people on how to choose the right spouse and to comply with the principles of successful marriage in conformity with the norms of the Islamic Sharia.

The rights to life, safety and development of a child are considered from the moment a child begins to form from an embryo that should be protected and secured, according to the Islamic doctrine. A child in this form is considered as an already living human being created by Allah, despite the fact that it is still in the womb. This implies obligatory provision of health care and healthy food to a pregnant mother. Muslim husband is compelled to provide his pregnant wife with financial support. The Almighty said: "And if they are pregnant, then spend on them till they lay down their burden" [6].

According to Muhammad's assumption reflected in hadithes of Muslim and al-Bukhari, a fetus that is less than 120 days has no soul yet: "Indeed, any of you (at the beginning) is formed in the womb of your mother within forty days in the form of a drop, then it remains there as a clot for forty days and for forty more days in the form of a little lump of flesh, and the Allah sends an angel who should write down four things. He is told: "Write down his deeds, his destiny, his lifetime period and if he will be happy or unfortunate", after that he is forced in with the spirit" [7].

According to that, Article 2 of the Cairo Declaration on Human Rights presupposes that life is a gift of the Almighty and a guaranteed right to everyone. People, society and state are obliged to protect this right from any offences; life cannot be taken, unless otherwise specified by Sharia. Protection of human life during the time given by Allah to an individual is a compulsory prescription of Sharia [8].

The moment of beginning a human life is considered in medical and legal literature as practically significant. Development of auxiliary reproductive techniques and new the then-unheard-of possibilities, post-mortal reproduction programmes, the problem of life of the embryo and right of the child to be born grows in significance not only in the ethical sense, but in the civil and criminal law [9]. Meanwhile, we should admit that this problem is viewed from various angles.

The absolutist position is based on absolute value of a human embryo at all levels of its development [10], because from the biological point of view a human being as a biological individual is formed right after the fusion of parents' cells creating a unique set of genes. As a biological structure, the embryo is not similar to any female organ, because it is a human being growing inside its mother's body. The embryo is a 'future human being' rather than a part of a female body.

It is for protection of the embryo's life that Islam prohibits abortion, unless its mother can be removed from a real threat only by way of abortion. It is based on general prohibition on murder: "You should not kill any living being whom Allah has forbidden to kill except by right" [11].

Legitimacy of abortion in case of real threat to mother's health rests on several Sharia principles, including, for instance, the principle of an urgent situation: "Unless you are forced to do it", and the one that life of a mother is more important than the embryo's life, because the former is basis, while the embryo is its derivative. According to the Almighty: "No mother should be harmed through her child" [12]. In fact, it deals with choosing between the bad and the worst - mother is already alive and keeps living, while a child's life is a probability, which is yet unreal. Nevertheless, Islam prohibits doing the embryo any harm, therefore it allows a pregnant woman not to keep a fast during the Ramadan and compensate it later [13].

Doing the embryo any harm or any attempts to take its life are flatly banned in Islam - it is a human being created by Allah and no one has a right to take its life, even its father or mother. It is symptomatic that even in case pregnancy is resulted from a sinful impregnation, a mother would be prohibited to make abortion, because a child is not guilty for deeds of its parents. The Almighty said: "No bearer will bear the burden of another" [14]. It should be pointed out that this prescription is reflected in Preamble of Declaration of the Rights of the Child of 1959, which goes as follows: "The child, by reason of his physical and mental immaturity, needs special safeguards and care, including appropriate legal protection, before as well as after birth" [15].

Meanwhile, the problem of determining initial period of a child's life was debated much during discussions of the Preamble and Articles 1 and 6 of a project of Convention on the Rights of the Child of 1989. Thus, the mission from Vatican suggested inserting a phrase from the Declaration of the Rights of the Child of 1959 "before as well as after birth" into one of the paragraphs of the preamble of the Convention. This suggestion was supported by members of the Working group who had opposite views.

Those who supported the suggestion of the Vatican mission explained their position by the fact that their national laws contained provisions concerning protection of rights of the child from the moment of conception. This position was supported because it is relatively neutral to the problem of abortion and doesn't indicate the moment from which protection of the unborn child begins. Those who were against this position referred to the fact that every nation has their own laws concerning abortion, therefore if they accepted the provision it would not allow many states to ratify or join the 
convention. As a compromise, they suggested avoiding any references to than in the convention. This opinion was supported.

Fierce debates took place when discussing Article 1 containing definition of a child. Missions that supported conceptions establishing the moment of fertilization as the beginning of life suggested that this provision should be included into the definition of a child. As a result, the Article reads as follows: "For the purposes of the present Convention, a child means every human being below the age of eighteen years".

In complete conformity with the Christian views (Vatican's view), throughout its development the embryo should be considered as a valuable human being enjoying the right to life from the very beginning - linkage of a male and a female gametes. This helps to grow a zygote with a unified nucleus containing a unique and a specific programme of development of the future human being. Pregnancy is just the process of maturation and growing of a new human being. This approach corresponds to basic ideas of the Islamic Sharia.

Among international treaties of a regional character containing guarantees of rights of the child, special attention should be paid to the Cairo Declaration on Human Rights in Islam of 1990 [16]. In this respect, we can hardly disagree with I. A. Mikhailovsky, who suggests that "no other subjective civil law can have such a complex subject-matter embracing medical, philosophical, biologic, religious and legal constructions, peculiar mixture of which reveal itself in all aspects of life - from the moment of development of this right, i.e. the right to life of the conceived but unborn children" [17].

In literature the embryo is considered as a human creature having a value and the right to live from the moment of conception. Therefore it is prohibited to perform any actions that could complicate or terminate its development. Thus, the state should provide conditions for development and protection of life at any stage. A renowned religious figure Imam AlGhazali believes that abortion is a crime against an already living human being. He considers conception as "readiness to get life".

Analysis of the modern legislation of the Republic of Yemen revealed some inconsistency relevant the subject under examination. Thus, the Constitution of the Republic of Yemen of 2001 doesn't specify the moment when human rights take their legal effect. If, as a comparison, we refer to Article 16 of the Constitution of the Russian Federation we can see that it reads that "fundamental human rights and freedoms are inalienable and shall be enjoyed by everyone since the day of birth".

Similar approach can be seen in the industry-specific legislation of the Republic of Yemen containing definition of the moment of birth. Thus, according to Article 320 of the Criminal Code of the Republic of Yemen of 1994 stipulates that the moment of birth of a child is the moment of separation of a fetus from a mother's organism by way of delivery, when it can breathe and shows other vital signs (crying, sneezing, breathing or moving). In the context of comparative legal studies, it should be mentioned that these provisions are similar to those of Article 49 Section 1 of the Federal Law of the Russian Federation "On Fundamental Healthcare Principles in the Russian Federation" stipulating that the moment of birth of a child is the moment of separation of a fetus from a mother's organism by way of delivery. The Civil Code of the Republic of Yemen of 1991 (Article 37) determines that a human being acquires personality at the moment of birth and loses it at the moment of death.

Meanwhile, according to the Law of the Republic of Yemen No (45) from 22/9/2002 "On the Rights of the Child", the state should provide medical assistance to a child during pregnancy, delivery and after the birth. Article 68 of the aforesaid Law establishes responsibility of the state to provide necessary treatment or surgical intervention the soonest possible in order to avoid any kind of obstacles or harm to a child's health in the future. Legal rights of the child are applicable both to the embryo and a child after the birth (cт.70).

At the same time we proceed from the assumption that, according to Article 4 of the mentioned Law, the right to life is absolute and cannot be diminished.

As a comparison, we should mention that the Federal Law "On Fundamental Guaranteed of Rights of the Child in the Russian Federation" from July $24^{\text {th }}, 1998$ stipulates that health care organs should protect a child from any arbitrary interference restricting its right to life. It may be assumed that health care organs are obliged to take measures helping to protect rights and legal interests of the conceived but unborn children. This is not so much determined by legal acts as a complex interpretation of the Russian legislation. Thus, Article 3 of the Federal Law "On State Benefits for Citizens with Children" from May 19th 1995 presupposes a number of maternity allowances, lump-sum allowances for those who registered in medical institutions during early pregnancy, and not only after the child is born. It seems that maternity allowance is paid not only for supporting mother's health but for protecting the health of an unborn child, i.e. it meets with a child's interests as well.

This is proved by the fact that a conceived child may be considered a lawful heir long before the birth. According to Article 1116 of the Civil Code of the Russian Federation, a child conceived while its ancestor is alive can be called for 
inheritance. In legal literature reasonable consideration is given to the fact that, when it comes to a conceived child as an unborn legal heir, the procedure of certification of inheritance rights should be delayed, inheritance can be distributed only after this legal heir is born (see Articles 1166, 1163 of the Civil code of the Russian Federation).

Modern criminal legislation of the Republic of Yemen doesn't contain specific norms designed to protect the life of a fetus (the embryo) during the prenatal development and deliver. It should be pointed out that if termination of pregnancy was made by forth actions of the offender they are qualified as willful actions in accordance with Article 239 of the Criminal Code of the Republic of Yemen (Abortion made without consent of a pregnant woman) or Article 240 of the Criminal Code of the Republic of Yemen (Abortion made with consent of a pregnant woman).

Article 234, section 2, of Abortion made without a consent of a pregnant woman (Intentional homicide), the same as Article 105, section 2, sub-section "g" of the Criminal code of the Russian Federation, considers murder of a woman known by the killer to be in a state of pregnancy as one of the qualified corpus delicti. It can be assumed that, to some extent, in this case the fetus (the embryo) is yet implicitly protected. Responsibility is strengthened by the fact that harm is doubled (this is a murder of not only a woman, but a fetus (an embryo). According to Article 239 of the Criminal Code of the Republic of Yemen (as well as to the Article 111 of the Russian Federation), the criminal responsibility is incurred irrespective of the fact if any harm to the health of a pregnant woman was made. The very fact of termination of pregnancy resulting from the offender's actions is enough.

According to the legislation of the Republic of Yemen, the fetus has a right to be in family relations with its lawful father and mother after the birth see Articles 14, 15, 20, 21 of the Law "On Rights of the Child in the Republic of Yemen"). With regard to this fact, it is prohibited to perform any actions that could provoke doubts on account of blood ties between a child and its parents. The issue of blood ties between a child and its parents is of much significance in the Islamic Sharia. However, this prescription is not absolute in a sense that it is related to natural children only. The Islamic Sharia prohibits adultery, prescribes the waiting period after the divorce (iddah) for the divorced or widowed people and allows marriage only after the end of this period in order to secure blood ties from mixing. Those who study fundamentals of Islam consider that preservation of kindred is one of the main objectives of Sharia. The Almighty Allah said: "Call them by the names of their fathers; it is more just in the sight of Allah. But if you do not know their father, then they are still your brothers in religion and those entrusted to you. And there is no blame upon you for that in which you have erred but only for what your hearts intended. And ever is Allah Forgiving and Merciful" [18]. In Islam an illegitimate child is considered a human being enjoying all rights bearing no responsibility for the actions committed by its parents. Thus, according to the Article 1035 of the Civil code of the Republic of Yemen, heirs on testacy and at law are any citizens conceived while their lawful ancestor was alive and born alive after the testimony is opened.

Thus, it should be pointed out that the legislation of the Republic of Yemen relevant the subject under study features some contradictory elements and flaws. According to laws, human being acquires legal competence exclusively after the birth. On the constitutional level, before the birth the embryo is not explicitly protected from any attacks to its life. We assume that Article 30 of the Constitution of the Republic of Yemen should be amended with the following wording: "The state shall guarantee that a human life is protected from the moment of conception". The corresponding amendments should be made to other legal acts. This provision doesn't contradict in any aspect to the mentioned international legal acts.

\section{References}

Quran. Surah "The Believers", ayat 12-13 (in Arabic)

Article 91 of the Islamic Family Code of 2006 (in Arabic). URL: http://www.iicwc.org/lagna/catig/methak/ar/

Quran. Surah «The Cave», ayat 46 (in Arabic)

Quran. Surah «The Council», ayat 49-50 (in Arabic)

Quran. Surah «The Divorce», ayat 65 (in Arabic)

Muhammad bin Ismail Bukhari. Sahih bukhari, Dar Ibn Kasir, Damascus, 1993, P. 1175. (in Arabic).

Cairo Declaration on Human Rights in Islam, adopted at the summit of the Organization of the Islamic conference, August $5^{\text {th }} 1990$. A/45/421 UN General Assembly. P. 122.

See: Svitnev, Legal Status of the Embryo in the international Law (law enforcement practice) URL: http://medadvocat.ru/ view_page.php?page=128

See: Perevozchikova, E. V., Pankrtova, E.A. Constitutional Right to Life and Legal Status of the Human Embryo. Medical Law, 2006, No 2. P. 16-22.

Quran, Surah «The Cattle», ayat 151. (in Arabic)

Quran, Surah «The Cow», ayat 233. (in Arabic)

Anas ibn Malik informs that Muhammad, the messenger of Allah, said: «Indeed, Almighty Allah deprived the traveler from a fast and 
prayer, and the pregnant or breast-feeding woman from a fast" (Authentic Hadith. By Tirmisi and Nasai).

Quran, Surah «At night», ayat 15. (in Arabic).

Declaration of the Rights of the Child, Resolution 1386 UN General Assembly, November 20 ${ }^{\text {th }}, 1959$

Cairo Declaration on Human Rights in Islam, adopted at the summit of the Organization of the Islamic conference, August $5^{\text {th }} 1990$. A/45/421 UN General Assembly. P. 122.

Mikhailova, I. A. Right to Life: Problems of Legislation. The Russian Judge, 2005, No 8. P. 23.

Quran, Surah «The Cow», ayat 228 (in Arabic) 
